\title{
Characterization through Speech in Fiction and Literary Translation
}

\author{
Maria Yu. Rodionova* \\ Nizhny Novgorod State Linguistic University \\ 31a Minin Str., Nizhny Novgorod, 603155, Russia
}

Received 12.02.2018, received in revised form 16.04.2018, accepted 27.04.2018

\begin{abstract}
Speech portrait of a literary personage is important for characterizing the personality, for distinguishing them from other characters, for helping the reader to compare personages as well as for showing their inner life and their psychotype. Comparison of the two central characters of Dostoevsky's "The Idiot" (Myshkin and Rogozhin) in the original text and in one of its many translations shows how the translator's failure to reproduce Rogozhin's speech portrait and its dynamics in the novel neutralizes the contrast between the two characters thus ruining the major opposition underlying the book.
\end{abstract}

Keywords: literary character, speech characterization, functions, translation, emotions, contrast.

DOI: 10.17516/1997-1370-0273.

Research area: linguistics, culturology.

\section{Introduction}

The image of a literary character is composed of many things, such as the person's disposition and temperament, appearance, education, hobbies and inclinations, social environment, status, self-concept, attitude to others. They all contribute to the psychological and social portrait of the character that is revealed to the reader not only through the person's actions and behavior, but also through the way they speak.

Speech characteristics are used by authors as markers of age and gender, of education and profession, of social status and emotional state, of the attitude to people and events. That is why there is a certain correlation here that works both ways: on the one hand the character's manner of speaking helps to recognize their social status and education, and on the other hand this information helps to interpret peculiarities of their speech.

\section{Speech portrait in a literary text}

In a literary text the way characters speak is an important device used for portraying them and revealing their inner life. So, characters that differ in age, temper, profession, etc. also differ in the way they speak.

There are several functions that speech peculiarities can fulfill. The number of these functions varies with various scholars. However the following four are found on the majority of lists (see for example (Borunov, Malygin, 2013)). The first one is a characterizing function. It helps to individualize the personage, show their unique traits, their status and breeding. Changes in the

(C) Siberian Federal University. All rights reserved

* Corresponding author E-mail address: maria.y.rodionova@gmail.com 
way a person speaks can also reflect changes in their disposition and development of their character.

The next function is distinctive. It shows how the character differs from other personages, highlights a contrast between them.

Speech characterization can also fulfill a comparative function. The way personages speak makes it easy to compare them, their reactions and behavior in the same situation, within one episode.

There is also a psychological function of speech characterization because a person's manner of speaking reflects their inner world, their psychological type.

Speech characterization can be achieved in two ways - indirectly, that is by means of the author's description of the way the characters speak, and directly, through peculiarities of speech itself. The author's descriptions can also include nonverbal manifestations, such as facial expression, gestures and motions accompanying speech, as well as intonation and speech melody that are essential components of a person's speech. It is not enough to know what is said. It is also necessary to know how it is said, because by changing the intonation of an utterance it is possible to alter its meaning without changing its grammatical structure or words.

Peculiarities of characters' speech can be divided into two groups. The first group is represented by speech peculiarities typical of a certain group of people. It comprises units of colloquial speech, local dialects, jargon, slang. The second one consists of speech peculiarities that are individual and unique. They can be speech defects (speaking with a burr, lisp, confused articulation, etc), inappropriate familiarity of speech. Individual speech peculiarities can be represented by an excessively frequent use of certain words. Sometimes the speech of a character is overloaded with "empty" and filler words to show that a character is tongue-tied. Another example of speech characterization is the manner of speech which can be either intently bookish or laconic.

Speech peculiarities can be implemented at morphological level when a character tends to use a certain morpheme excessively (diminutive Russian suffixes would be a good example). At the syntactical level a character's speech can be rich in certain types of syntactical structures; a person can use either too short or too long sentences. Some of these peculiarities are individual speech characteristics, but sometimes they are speech characteristics of a family, a group of friends or some other social group (Vladimirova, 2006).

As they are not markers of age, gender, education, profession and social status, individual speech peculiarities are identified in the text with the help of the "method of exclusion" (Vladimirova, 2006). They constitute a challenging task for a translator - a creation of an individual speech style with means of another language. A character's individual style must be sustained throughout the whole book. When translating a literary text one cannot neutralize such peculiarities without damaging the image of a character. On the other hand, it is nearly as dangerous to overdo it, to exaggerate individual speech peculiarities thus making the image seem grotesque. In either case it may lead to substantial distortions of the character's portrait. Apart from being a means of creating a particular image, a character's idiolect sometimes helps the reader to perceive the ideas that are not explicitly expressed, but only implied by the author (Korableva, 2010). That's why all peculiarities that mark a personage's speech in the original should characterize their speech in translation to the same degree. There are no rules and instructions as to how speech peculiarities should be rendered in translation, though it's obvious that it requires significant alterations of the original, since any idiolect is an individual's distinctive and unique 
use of a particular language. Translation in such cases equals to creating a functionally similar idiolect in a different language.

To see how crucial it is to render all peculiarities of speech characterization in translation, F. Dostoevsky's novel "The Idiot" (Dostoevsky, 2002) and one of its translations (McDuff, 2004) were chosen for the analysis.

\section{Speech portrait of Prince Myshkin in the novel}

The author is known for his talent to portray a vast and vivid variety of characters and to reveal psychological and emotional depths which are reflected in speech peculiarities of his characters. Every detail of a speech portrait is significant and valuable.

From the very beginning of the novel the main character Prince Lev Nikolayevich Myshkin comes back to Russia after many years spent in Switzerland. He is sincerely happy to speak Russian, his native language. He welcomes the opportunity to start a conversation with his fellow travelers in the train carriage. While living in Switzerland he didn't have a possibility to speak Russian but he "managed to read a very large number of Russian books", that's why his manner of speech is somewhat bookish. Sometimes he does not understand the meaning of colloquial and vulgar phrases or jokes. He hardly ever tells jokes himself and never uses any vulgar words.

In Switzerland he spent a lot of time talking to children, so he uses "school words" in his speech, like «срезаться, отрапортоваться больным», which are not quite clear to adults.

- Послушайте, Аглая, - сказал князь, - мне кажется, вы за меня очень боитесь, чтоб я завтра не срезался... в этом обществе?

- За вас? Боюсь? - вся вспыхнула Аглая, - отчего мне бояться за вас, хоть бы вы... хоть бы вы совсем осрамились? Что мне? И как вы можете такие слова употреблять? Что значит: “срезался”?

Это дрянное слово, пошлое.

- Это... икольное слово.

- Знаете что: я лучше завтра совсем не приду! Отрапортуюсь больным, и кончено! - решил он наконец.

- Прекрасно сделаете. Bbl сейчас сказали: “отрапортуюсь больным”; откуда вы берете в самом деле этакие выражения? Что у вас за охота говорить со мной такими словами? Дразните вы меня, что ли?

- Виноват; это тоже школьное слово; не буду.

The author portrays Prince Myshkin as an absolutely positive man, who is capable of compassion and sympathy, whose heart is open to other people. His inner emotional world, his sensitivity is reflected not only in his speech but also in his nonverbal behavior. All his gestures, facial expressions, laughter are always in harmony with his speech. His smile or laughter means sincere happiness, not mockery. Prince Myshkin is eager to join any conversation with other characters and tells them a lot about his life abroad. But at the same time, he is a good and attentive listener who hardly ever interrupts his interlocutors.

Sincerity, honesty, openness, naivety verging on the simplicity of a child are his main peculiarities when he communicates with other characters. Behaving like that he doesn't pursue any aim: he is frank, ingenuous and open-hearted talking to everybody, whether it be Nastasya Filippovna, Aglaya or Rogozhin.

Prince Myshkin is rather emotional and his emotions are reflected in his speech.

Ну, как я рад! - радостно вздохнул князь: - я таки за него боялся!

But his emotions are not always positive. In the climax scene of the novel, when Prince 
Myshkin gets to know that Nastasya Filippovna was murdered, his manner of speech changes significantly. It is no longer well-balanced and syntactically complete, but abrupt and incoherent.

- Постой; что же ты теперь, Парфен, как же хочешь?

Emotions may affect mental processes that regulate speech behavior so greatly, that it becomes quite difficult for Prince Myshkin to formulate what he wants to ask and it requires some time to put his thoughts into words.

- Стой ещуе! Я, Парфен, ещче хочу тебя спросить... я много буду тебя спрашивать, обо всем... но ты лучше мне сначала скажи, с первого начала, чтоб я знал: хотел ты убить ее перед свадьбой, перед венцом, на паперти, ножом? Хотел или нет?

But all in all, when he is not influenced by such grave emotions Prince Myshkin is perceived by the reader as a person who is eager to communicate with others and who speaks clearly and intelligibly, expressing various tinges of this emotional state.

\section{Speech portrait of Rogozhin} in the novel

The comparative function of speech characterization is fulfilled in the episode when Prince Myshkin gets acquainted with Rogozhin, who is the first person with whom Prince Myshkin speaks in Russia. At first sight they are very much alike: “...both young men, both with almost no luggage to speak of, both unostentatiously dressed, both with rather remarkable facial features, and both wishing to enter into conversation with the other». But the next moment they are opposed to each other: one of them «with almost black curly hair", dressed "in a wide, black wool-lined sheepskin overcoat", who "had not felt the cold overnight" starts to speak with the other one, a young man "with very thick, fair hair", dressed in "a rather capacious, thick sleeveless cloak with an enormous hood", who "had been compelled to endure on his shivering back all the delights of a damp November Russian night”. This opposition is underlined by Rogozhin's speech behavior.

His associates are half-drunk fellows who accompany him everywhere. This fact couldn't but influence his speech: he speaks expressively, with a great number of slangy and invective words, uses substandard, vernacular and rusticated language. His speech is often accompanied with laughter and whistle.

\author{
- Из-за границь, что ль? \\ - Да, из Швейияарии. \\ - Фью! Эк ведь вас!.. Черноволосый присвистнул \\ и захохотал.
}

A deliberate and excessive use of vulgar and low colloquial words («mьфy чорт») and his flaunty inclination to speak substandard language («штиблетишки-то», «али какую xоmb») characterize him as an arrogant and haughty person whose behavior is a challenge if not an affront to society.

- Эге! Да ты вот что! - действительно удивился, наконеч, Рогожин; - Тьфу чорт, да ведь он и впрямь знает.

- Приходи ко мне, князь. Мы эти итиблетишки-то с тебя поснимаем, одену тебя в кунью шубу в первейшую; фрак тебе сошью первейший, жилетку белую, али какую

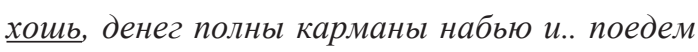
к Настасье Филипповне! Придешь, али нет?

So, in the first scene which takes place in the train carriage when Rogozhin and Prince Myshkin get acquainted, a somewhat neutral, a bit bookish, but grammatically correct and logically 
built speech of Prince Myshkin is sharply contrasted with the speech of Rogozhin which is expressive, arrogant, coarse with a number of rusticated, curse and swear words. These are the characters the reader sees at the beginning of the novel.

With the help of speech characterization, it is possible not only to compare the characters but also to follow their evolution and development and to gain an insight into their inner world. Having got to know him better, Rogozhin realizes that Prince Myshkin differs from other people, he is not like them. Rogozhin's manner of speaking changes when he is talking to Prince Myshkin: vulgar, slangy and invective words disappear from his speech. He feels embarrassed, perplexed, annoyed and sometimes irritated; he loses his self-confidence and self-assurance when he speaks to Prince Myshkin.

Наконеи, Рогожин усмехнулся, но несколько смутивиись и как бы потерявиись.

- Что ты так смотришь пристально? пробормотал он: - садись!

- Что ты приедешь, я так и думал, и видишь, не ошибся, - прибавил тот, язвительно усмехнувшись, - но почем я знал, что ты сегодня nриедешь?

Некоторая резкая порывчатость и странная раздражительность вопроса, заключавшегося в ответе, ещуе более поразили князя.

- Вона! Чьи же были глаза-то? - подозрительно пробормотал Рогожин. Князю показалось, что он вздрогнул.

- Что ж, может и померещилось; я не знаю... бормотал Парфен.

Rogozhin speaks quietly without his usual loud laughter, often mumbling in a low voice.

It was said above that thanks to the psychological function of speech characterization emotions of the characters are revealed to the reader. In the climax scene of the novel when Rogozhin leads Prince Myshkin to the murdered Nastasya Filippovna, he suffers the deepest emotional shock and disruption. In this episode his speech does not differ from the speech of Prince Myshkin, who experiences the same emotions.

- Вот что, Лев Николаевич, ты иди здесь прямо, вплоть до дому, знаешь? А я пойду по той стороне. Да поглядывай, чтобы нам вместе...

He keeps to that manner of speaking during their long conversation with Prince Myshkin after he has murdered Nastasya Filippovna.

- Так я и порешил, чтоб ни за что, парень, и никому не отдавать! Ночью проночуем тихо. Я сегодня только на час один и из дому вышел, по утру, а то всё при ней был. Да потом по вечеру за тобой пошел. Боюсь вот тоже еще что душно, $и$ дух пойдет. Сльиииь ты дух или нет?

From his rich repertoire of vernacular and rusticated words, which overload his speech in the scene of their first meeting in the train carriage, Rogozhin constantly uses only one word «парень», which is used as a form of address.

- Постойже, я пока нам постель постелю, и пусть уж ты ляжешь... и я с тобой... и будем слушать... потому я, парень, еще не знаю... я, парень, еще всего не знаю теперь, так и тебе заранее говорю, чтобы ты всё про это заранее знал...

This word is hardly addressed to Prince Myshkin. In this episode Rogozhin seems to address himself. His speech resembles an inner monologue spoken out loud because of the emotional disarray caused by the murder.

So, the analysis of speech behavior of Prince Myshkin and Rogozhin shows how 
speech characterization fulfills characterizing, comparative and psychological functions.

\section{Speech characterization in translation}

Speech characterization rendered in translation should fulfill the same functions in order to make the text of the translation equal to the original. Let's analyse speech peculiarities which help to characterize and compare Prince Myshkin and Rogozhin in translation. The way Prince Myshkin speaks in the translation is similar to his manner of speech in the original. But as for Rogozhin, his speech in the translation differs significantly from that one of the original. All speech peculiarities (vernacular language, swear words, expressive exclamations, abrupt and half-finished sentence structures etc.) that make his speech different are not rendered in translation.

- Эвона! Да мало ль Настасий Филипповн! И какая ты наглая, я тебе скажу, тварь! Ну, вот так и знал, что какая-нибудь вот этакая тварь так тотчас же и повиснет! - продолжал он князю.

'Get away with you! There are lots of Nastasya Filippovnas! And you're an insolent creature, too, I'll tell you that! You know, I had a feeling some creature like this would start latching on to me!' he continued.

The vernacular exclamation «эвона!» is renedered by "Get away with you!" which corresponds to Russian jokey phrases like «да брось ты!», «Да ну тебя!» and can be a characteristic as colloquial. The word «тварь», which is used as a swear word in the original, is rendered by the word "creature", which doesn't function as a swear word.

In the following example in the original some grammatical structures which are used by Rogozhin are typical of vernacular or rusticated speech «nуще всего брат доехал»), though in translations he speaks with the constructions that are markers of formal style and literary language: "he had a good reason for that", "who really annoyed me", "as far as she is concerned".

- Рассердился-то он рассердился, да, может, и стоило, - отвечал Рогожин, - но меня пуще всего брат доехал. Про матушку нечего сказать, женщина старая, Четьи-Минеи читает, со старухами сидит, и что Сенька-брат порешит, так тому и быть

'He just got angry, and perhaps he had good reason for that,' Rogozhin answered, 'but it was my brother who really annoyed me. One can't blame Mother, she's getting on in years, reads the Lives of the Saints, sits with the old women, and whatever brother Senka decides is right as far as she's concerned.

The use of the phrase "as far as she's concerned" speaks of the translator's intentional elevation of style, because it actually does not correspond to the Russian «так тому и быть» semantically and seems to be an attempt to avoid its semantic and stylistic equivalent "then so be it".

As a result of not rendering the peculiarities of Rogozhin's speech, the recipient of the translation gets acquainted with another Rogozhin who does not coincide with the Rogozhin of the original.

It is mentioned above that the analysis of Rogozhin's speech behavior in the original shows that his speech habits are changing as his interaction with Prince Myshkin is developing. He speaks quietly, not so expressively and does not allow himself to use vulgar and swear words. That is just the way Rogozhin speaks in the translation.

\section{Князь встал.}

- Посиди со мной, - тихо сказал Парфен, не подымаясь с места и склонив голову на правую ладонь: - я тебя давно не видал. 
Князь сел. Оба опять замолчали. - Я, как тебя нет предо мною, то тотчас же к тебе злобу $и$ чувствую, Лев Николаевич. В эти три месяца, что я тебя не видал, каждую минуту на тебя злобился, ей богу. Так бы тебя взял и отравил чем-нибудь! Вот как. Теперь ты четверти часа со мной не сидишь, а уж вся злоба моя проходит, и ты мне опять по-прежнему люб. Посиди со мной...

The prince stood up.

- Sit with me for a while,' Parfyon said quietly, not getting up from his seat and leaning his head on his right palm. 'It's a long time since I've seen you.'

The prince sat down. They both fell silent again.

- When you're not there in front of me, I at once feel malice towards you, Lev Nikolayevich. These last three months, when I haven't seen you, I've felt bitter towards you every moment, by God, I have. I could have gone and poisoned you! It was like that. Now you've scarcely been sitting with me for quarter of an hour, yet all my malice is passing, and you're as dear to me as you used to be. Sit with me for a while...'

In this episode the way Rogozhin speaks in the original is similar to that found in the translation. But in the course of the novel the dynamics of development of the character implied by the author is lost. In the original the speech portrait of Rogozhin changes significantly, while in the translation it remains the same.

Let's analyze another situation showing how the loss of some speech peculiarities showing the emotional state of the personages, alters this state: the characters appear to be calm and composed, though in fact they are either excited or dispirited and depressed. Having prevented Canya from slapping his sister in the face, Prince Myshkin feels agitated and perplexed. He gets the slap in the face himself and he needs some time to collect himself, so his speech is abrupt and faltering.
- Ну, это пусть мне... а ее все-таки не дам!.. - тихо проговорил он наконец; но вдруг не вылержал, бросил Ганю, закрыл руками лицьо, отошел в угол, стал лицом к стене и прерываюшимся голосом проговорил...

But in the translation his speech is organized in grammatically well-built and fully predicative sentences.

-Well, you may do it to me... but I won't let you do it to her!...' he said quietly, at last; but suddenly lost his nerve, abandoned Ganya, covered his face with his hands, went off into a corner, stood with his face to the wall, and said in a faltering voice...

In the final scene when both Prince Myshkin and Rogozhin get shocked and frightened, the way one of them speaks does not differ from that of the other. In such emotional state they experience difficulties in expressing themselves. Their speech is marked by incoherent and grammatically incomplete phrases, repetitions and other deformations that affect syntactical structures. The phrase, which was mentioned above to illustrate that emotions experienced by Prince Myshkin prevent him from speaking logically and coherently, is translated by a phrase with good grammar and logic.

- Постой; что же ты теперь, Парфен, как же хочешь?

- Wait; what will you do now, Parfyon, what are your plans?

The same happens with the speech of Rogozhin. In the original he is greatly excited as he pronounces his abrupt phrase fervently. In the translation, his speech is well-balanced and syntactically complete. It can't be associated with a person who speaks in great agitation. 
- Значит не признаваться и выносить не давать.

- That means there'll be no confession and we won't let them take her out.

So, in this episode Rogozhin is perceived by the reader of the original as a person who is excited and agitated about the course of events, but to the recipients of the translation he appears to be calm and composed.

- Купить разве... - пукетами и ивветами всю обложить? Да думаю, жалко будет, парень, в иветтах-то!

- Perhaps if I were to buy some, and put bouquets and flowers all round her? But, friend, I think I'll feel sorry for her, seeing her all covered in flowers!'

The grammatically incomplete and logically incoherent phrase of the original is rendered by a phrase which is logically built and grammatically well-formed. That seems quite inappropriate in a speech of a person who is frightened, perplexed and embarrassed. In the original the character is surely puzzled because he is not quite sure what to do. In the translation, he appears to be cool-headed and sensible and is capable of considering the situation reasonably. He speaks as a cool-headed murderer, and not as a person who becomes half-insane because of what he has done.

\section{Conclusion}

Having compared the peculiarities of speech characterization of Prince Myshkin and Rogozhin in the original text and in its English translation, it is possible to conclude that they do not always coincide. Because of the translator's tendency to render emotional speech neutrally the character of Prince Myshkin speaks logically and coherently at the moments of the deepest emotional agitation or depression. In other situations, the speech of Prince Myshkin in the English translation is similar to the way he speaks in the original text. Myshkin's speech is of a neutral and literary style, it demonstrates the absence of any vulgar or swear words. He speaks without any mockery that usually aims to offend interlocutors. These are the main peculiarities which characterize his speech in the original and they are preserved in the translation. But there are reasons to believe that it is not a result of the translator's intentional attempt to render the style and manner of speech adequately. It rather happens because Dostoevsky's Prince Myshkin, unless he is under stress, speaks a bookish, grammatically correct and stylistically neutral language - exactly the type of language the translator invariably uses for rendering the author's narration as well as the speech of all characters throughout the novel, neutralizing stylistic register and restoring broken speech constrictions.

Because of this tendency the character of Rogozhin is not rendered so vividly in translation. His ostentatious manner of speech full of vulgar and curse words is ameliorated. In the translation he does not appear as a person who suffers great emotional disarray, he speaks clearly and calmly. And he keeps to that manner of speech from the very beginning of the translated text till its very end. So, the character of Rogozhin in translation does not evolve as the Rogozhin of the original does. He seems to be some other character and not the one created by Dostoevsky.

Such loss of speech peculiarities leads to some other consequences. The main idea of the novel implies an opposition of these two characters (Prince Myshkin and Rogozhin). In the numerous papers devoted to the analysis of the novel "The Idiot" there can be found different interpretations of these two characters, but what unites them is the idea of opposition of Prince Myshkin and Rogozhin. Some researchers speak about the opposition 
"Christ versus Antichrist" comparing Prince Myshkin with Christ and finding some correlation between Rogozhin and Antichrist. Others compare Dostoevsky's characters with Gods in Greek mythology and draw parallels between Prince Myshkin and Apollo, the god of prophecy, medicine and the Sun, and compare Rogozhin with Dionysus, the god of wine, who is usually associated with uncontrolled behaviour involving lots of drinking and entertainment. So, Prince Myshkin is opposed to Rogozhin like Apollo is opposed to Dionysus, symbolising confrontation between creating and destructive powers (Shhetinin, 2007). But whichever the interpretation it might be, it emphasizes the implied idea of opposition of these two characters. And speech portraits drawn by the author of the novel support the opposition. Dostoevsky makes his characters speak differently, but if in the translated version speech peculiarities are neutralized, it dims the contrast between the two. They remain opposed to each other in their deeds and thoughts, but their speech portraits do not add to that.

\section{References}

Borunov, A.B. Malygin, V.T. (2013). Sredstva sozdanija rechevoj portretnoj harakteristiki personazhej v tvorchestve R.N. Mitry [Means of Creating Speech Portrait Characteristic of Personages in R.N. Mitra's Creative Works], In Filologicheskie nauki. Voprosy teorii i praktiki, 8 (26), Tambov.

Dostoevskij, F.M. (2002). The Idiot, M: Jeksmo.

Dostoevsky, F.M. (2004). The Idiot. Translated by David McDuff Published by the Penguin Group. Penguin Books Ltd, London, England.

Korableva, N.Ju. (2010). Peredacha vozrastnyh i gendernyh osobennostej idiolekta (pri perevode proizvedenij hudozhestvennoj literatury s anglijskogo jazyka na russkij) [Rendering age and gender peculiarities of an idiolect (when translating fiction from English into Russian)]: avtoref. dis... kand. filol. nauk [synopsis of Candidat's dissertation (Philology)]. Moscow.

Shhetinin, R.B. (2007). Razvitie obrazov Myshkina i Pogozhina v romane F.M. Dostoevskogo «Idiot» [Development of Myshkin's and Rogozhin's images in Dostoevsky's novel "The Idiot"], In Vestnik Tomskogo gosudarstvennogo universiteta [Tomsk Stata University Journal of Philology], 304.

Vladimirova, Ju.I. (2006). Osobennosti rechevogo povedenija personazha hudozhestvennogo proizvedenija i perevod [Speech behaviour of fictional characters and translation], In Izvestija Rossijskogo gosudarstvennogo pedagogicheskogo universiteta im. A.I. Gercena [Izvestia: Herzen University Journal of Humanities \& Science]. 


\section{Речевая характеристика персонажа \\ художественного произведения \\ в оригинале и переводе}

М.Ю. Родионова

Нижегородский государственный лингвистический университет им. Н.А. Добролюбова Россия, 603155, Нижний Новгород, ул. Минина, 31 а

Речевой портрет литературного персонажа важен для характеристики этого персонажа, для выделения его среди других действующих лиц, для того, чтобы читателю было легче сравнить разных персонажей, а также для того, чтобы показать внутренний мир персонажа, его психотип. Сравнение речевых характеристик двух главных героев романа Ф.М. Достоевского «Идиот» (Мыикина и Рогожина) в оригинале романа и в одном из его многочисленньх переводов показывает, как отказ переводчика от воссоздания речевого портрета Рогожина и изменений, которые он претерпевает в романе, нивелирует контраст между персонажами, разрушая тем самым основную оппозицию, лежащую в основе всего произведения.

Ключевые слова: литературный персонаж, речевая характеристика, функиии, перевод, эмоции, противопоставление.

Научная спещиальность: 10.02.04 - германские языки. 